\title{
SELECTION AND EVALUATION OF GENETIC DIVERSITY IN POMEGRANATE I- Some criteria for studying the progenies of selfing, open-pollination and hybrid between Nab-El Gamal and El- Tahrir Cultivars
}

(Received: 3.6. 2014)

\author{
By \\ B. M. Khalil, N. A. Awd, A. O. Rayan and M. A. El-Hamady* \\ Horticulture Research Institute, Agriculture Research Center \\ * Faculty of Agriculture Kafr elsheikh University, Giza, Egypt
}

\begin{abstract}
Pomegranate breeding program was initiated in 2004 in the Horticulture Research Institute, Agriculture Research Center, Egypt. Breeding objectives are dedicated predominantly by the demands of the European markets and exploit the principal advantages of the Egyptian cultivars. It was initiated by crossing between the main cultivars (Manfaloty, Nab-El Gamal, El-Tahrir and Bader), selfing and open pollination for each cultivar. The aim of this study was to develop very early ripening genotypes of high productivity, dwarfing habit and good quality of fruits. About 200 progenies resulting from open, self-pollination and crossing among these cultivars were planted in Shandawel, Sohag Governorate in 2008. The progenies were studied to examine the inheritance of important traits. Some trees of these progenies flowered and gave fruits in 2012 and 2013 seasons; from which, nine trees were selected on the basis of the yield. The present investigation studied the polymorphism variance based on vegetative growth, flowering, fruit characters and yield of these progenies. DNA fingerprinting was determined through ISSR technique, using five primers to identify unique molecular markers characterizing the progenies under study. Some progenies, such as the hybrid between El-Tahrir x Nab-El Gamal (tree No 9) exhibited a yield of $22.5 \mathrm{Kg} /$ tree. Trees (No7 and No9) of the hybrid between El-Tahrir $+\times$ Nab El-Gamal ${ }^{\lambda}$ gave the best ratio of T.S.S/Acidity of 31.96 and 29.86 respectively, as compared to the other progenies. The hybrid tree (No7) between the same two cultivars was the smallest tree compared with all the progenies under study. Open pollination progeny of Nab-El Gamal gave the highest number of pomegranate grains in $100 \mathrm{~g}$, while the self pollination progeny of El-Tahrir gave the highest juice percentage. A dark color of the grains was detected for the

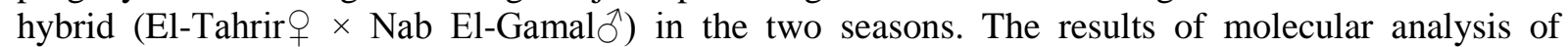
genomic DNA of the nine trees (progenies) of pomegranate showed that the total number of amplicons amplified by the five primers was 57 with an average of 11.4/primer. The polymorphism ranged from $50 \%$ to $93.3 \%$. The size of the amplified band varied between the used primers, ranging from 115 to $128 \mathrm{bp}$. Genetic similarity value was very low among the three tested hybrids ranging between 0.0 to 0.06. The variations observed in the genetic similarity could be attributed to the effect of pollen grains on the genetic structure of the resulting genotypes. On the other hand, a high value of genetic similarity was observed in the self and open pollination progenies of Nab-El Gamal, while the self and open pollination progenies of El-Tahrir cultivar exhibited intermediate values of genetic similarity. This polymorphism renders these markers useful for further genetic studies in pomegranate progenies.
\end{abstract}

Key words: pomegranate, Punica granatum, selfing, hybrids, open-pollination, fingerprinting, ISSR.

\section{INTRODUCTION}

Pomegranate (Punica granatum L.) is one of the oldest known fruit species, originated in south west Asia and probably in Iran (DeCandolle 1967). According to Smith (1976), pomegranate behaves as deciduous under temperate climate, but behaves as an evergreen or partially deciduous in subtropical and tropical climate.

Pomegranate is considered as a monoecious species developing male and perfect flowers. three types of flowers are present on the same plant, i.e., male, hermaphrodite and intermediate. The ovary of the male flower is rudimentary, whereas that of the intermediate flowers is 
degenerate type (Nath and Randhawa, 1959a and $\mathrm{b}$ and Josan et al. 1979). Both self and cross pollinations are reported in pomegranate. Singh (1977) reported that it is an often cross pollinated crop whereas Nalawadi, et al. (1973) reported that it is a cross pollinated crop. The greater percentage of fruit set was observed by hand pollination and pollination under natural conditions, i.e., open pollination (Nath and Randhawa, 1959 b).

Pomegranate plants can be trained on single stem or in multi-stem system. Flowering of pomegranate depends on the conditions of the growing place and also the fruiting season. (Nalawadi et al., 1973). Singh et al. (1978) stated that the inflorescence developed from mixed buds is situated terminally on the previous season's growth as well as on old spurs. Mir et al. (2007b) showed that significant variation in all growth yield parameters existed due to various cultivars. Recently, a number of pomegranate cultivars was studied in temperate region and indicated a high range of variability in vegetative growth behavior.

Khodade et al. (1990) studied the seedling selections of P-23 cultivar during the early, middle and late stages of fruit development. Fruit size, weight and volume increased whereas, the specific gravity decreased gradually throughout fruit development. Morphology and fruit characteristics of wild genotypes were studied by Bist et al. (1994). Also Jalikop and Kumar (1998) found significant variation among 18 genotypes representing soft, semi-soft and hard-seeded pomegranate. Pasad and Banker (1999) evaluated pomegranate trees in different regions in the world to determine the degree of similarities among genotypes, while the flower behavior was studied by El-Kasses et al. (1998). Fruit quality characteristics were studied by Feng et al. (1998). Abou-El-Khashab et al. (2005) evaluated six pomegranate cultivars and stated that Nab-El Gamal gave the best fruit characteristics and yield, under Ali Mubarak farm conditions at South Tahrir Research Station.

Some parts of the Mediterranean area are considered as native lands of pomegranate. Almost all the varieties in the region (local type) are selected by unknown persons and propagated by vegetative propagation. The grown local material may be considered as the pomegranate primary gene pool. The hybridization between cultivated and wild forms is probably, still taking place (Zukovskiy, 1950). Thus wild forms would be the secondary gene pool. Genetic studies are rare, but some studies based on morphometric criteria have recently been performed to determine the degree of polymorphism within local material (Mars and Marrakchi, 1999).

Vechetel and Ruppel (1992) stated that carotene pigments were the most important photosynthetic pigments, and they prevented chlorophyll from the damage of absorbed energy by photoxidation. There are very few reports on molecular genetic studies with pomegranate. Only a handful of genes were isolated from $P$. granatum and deposited in Genebank. Most of the genes deposited are those involved in production of unsaturated fatty acids; genes that encode for parts of ribosomal RNA. A comparative work is now being conducted in several studies to study the level of their expression and the structural differences of these genes among pomegranate cultivars that display prominent differences in skin and aril colors. Molecular markers, such as AFLP, RAPD and ISSR, were reported by several groups. Although Jbir et al. (2006) and Zamani et al. (2007) concluded that pomegranates are highly polymorphic. Others concluded that the degree of polymorphism was surprisingly low (Aradhya, 2006 and Yilmaz et al., 2006). Some studies observed that the apparent phenotypical differences among pomegranate cultivars were not reflected in the polymorphism of the molecular markers. Obviously, many more markers should be isolated from pomegranates to enhance breeding and evolutionary studies.

The main objectives of this investigation are to (1) study the effect of open, self and cross pollination on some local pomegranate cultivars which are highly adapted to the Egyptian environmental conditions, (2) to develop new genotypes characterized by high productivity and dwarfing habit trees and fruits of good quality, soft-seediness or absence of seeds, skin of red coloration, resistance to fruit cracking and good post harvest quality.

\section{MATERIALS AND METHODS}

This study was initiated out in 2004 through a breeding program in the Horticulture Research Institute, Agriculture Research Center in Egypt, using some local pomegranate cultivars to develop new Egyptian cultivars, having high yield, good color, seed softness, early and late ripening and high percentage of juice. 
2.1. The first step of the program: was to produce the first generation progenies (open and self pollination and hand crossing between the four cultivars Manfaloty, Nab El-Gamal, ElTahrir and Bader).

Five mature uniform and productive trees of each cultivar were selected as a parent in all combinations of pollinations (open, selfing and crossing). These trees were grown in AlyMubarak farm at South Tahrir, Research Station, at a distance of $5 \times 5 \mathrm{~m}$, in a sand soil with drip irrigation. Flowers in all treatments (selfing and crossing), except the open pollination were protected from pollen contamination by using glyssine paper bags. Pollen grains of the four cultivars were collected from flowers at the balloon stage, spread on a paper at the laboratory for 24 hours to dry. Then, they were stored in a container and placed in desiccators at $4^{\circ} \mathrm{C}$. The flowers at balloon stage were emasculated (for applying crossing) by removing the anthers carefully. Emasculated flowers were hand pollinated with specific pollen to receptive stigmas using the rubber tip of a pencil. The pollinated flowers (except the open pollinated flowers) were bagged by using glyssine paper bags in all treatments to prevent any undesirable pollination. All possible cross combinations were made during 2004 season to produce the $F_{1}$ progeny. Fruits were picked ( $\mathrm{F}_{1}$ hybrid) at the end of the season, and the seeds of all combinations were extracted.

2.2. The second step of the program started in 2005 season. The extracted seeds were cold stratified in the refrigerator at $5-7^{\circ} \mathrm{C}$. After twothree weeks, stratified seeds were planted in boxes (filled with a mixture of sand: beatmoss at a ratio 1:1) in the greenhouse for one year in the Horticultural Research Institute in Giza. In the second year of seed germination (2006), the seedlings (progenies) were transferred into polyethylene bags, filled with the same mixture of soil. The remaining progenies of seedling belonged to Manfaloty (open, selfed and the cross Manfaloty x Nab -El Gamal); Nab -El Gamal (open, selfed and the cross Nab El Gamal $x$ Manfaloty); El-Tahrir (open, selfed and the corss El-Tahrir x Nab-El Gamal ); and Bader (only selfed).

2.3. The third step of the program: About 200 seedlings of these treatments were planted in Shandawel farm, Sohag Governorate in 2008 year. Seedlings were planted at a distance of $5 \times 5 \mathrm{~m}$. Nine trees of the progenies of open, selfing and crossing of El-Tarir xNab-El Gamal, which flowered and gave fruits, were selected on the basis of the yield. They were studied at 2012 and 2013 seasons, as follows:

2.3.1. Morphological characteristics: The data of the vegetative and flowering traits were measured. Ten shoots were labeled on each the progeny (tree) in different directions to measure the vegetative growth and flowering traits. Plant height, shoot length, shoot diameter, number of leaves, number of internodes and leaf area were recorded.

2.3.2. Fruit characteristics: Ten fruits from the previously tagged flowers were collected randomly at maturity stage. Fruit weight, fruit size, fruit shape, fruit room number and color of fruit were recorded. Also total soluble sugar, acidity, percentage of grains, number of grains in $100 \mathrm{~g}$ and percentage of juice were also recorded. Fruit set and yield for each progeny (tree) were studied in the two seasons 2012 and 2013.

2.3.3. Spectrophotometric determination of chlorophyll A and B and the total carotenoid contents of the small leaves of all the progenies (trees) under study were determined according to the method of Sukran et al. (1998) with some modifications.

2.3.4. Statistical analysis: all data were subjected to statistical analysis of variance ( $\mathrm{F}$ test) "ANOVA". Moreover, Duncan's multiple range test was used for testing the significant differences among the two means of treatments at the level of significant of $(\mathrm{P}<0.05$ and $\mathrm{P}<$ 0.01). Gomez and Gomez (1984).

\subsection{DNA Fingerprint}

2.4.1. Inter simple sequence repeat (ISSRPCR) procedure. Total DNA was extracted from young leaves as described by Porebski et al. (1997). Five ISSR primers were used for PCR amplification (Table 1). Each $25 \mu$ of the reaction mix contained $2.5 \mu \mathrm{l} 10 \mathrm{x}$ Taq buffer (Promega), $1.0 \mu \mathrm{l}$ dNTPs $(20 \mathrm{mM}), 2.0 \mu \mathrm{l}$ of $\mathrm{MgCl} 2(25 \mathrm{mM}), 1.0 \mu \mathrm{l}$ primer $(0.11 \mathrm{nmol} / \mu \mathrm{l})$, $2.5 \mu \mathrm{l}$ DNA template $(10 \mathrm{ng} / \mu \mathrm{l}), 0.2 \mu \mathrm{l}$ of Taq polymerase (Promega, $5 \mathrm{u} / \mu \mathrm{l}$ ) and sterile $\mathrm{H}_{2} \mathrm{O}$ to $25 \mu \mathrm{L}$.

Amplification was performed under the following conditions: $4 \mathrm{~min}$ at $94{ }^{\circ} \mathrm{C}$ for one cycle followed by 30 s at $94{ }^{\circ} \mathrm{C}, 45 \mathrm{~s}$ at $60^{\circ} \mathrm{C}, 2$ min at $72{ }^{\circ} \mathrm{C}$ for 35 cycles and $7 \mathrm{~min}$ at $72{ }^{\circ} \mathrm{C}$ for a final extension. The amplification products were separated by electrophoresis on $1.5 \%$ a garose gels with IX TBE buffer and detected with Ultraviolet light after ethidium bromide staining. 


\subsubsection{Data analysis}

A similarity matrix using the similarity coefficients of Nei and $\mathrm{Li}$ (1979) was constructed for ISSR data based on the presence (coded as 1) or absence (coded as 0 ) of the resulted fragments for each primer. Moreover, the relationships among the different progenies as revealed by " dendogram" were done using SPSS. Windows program (V.10)

Table (1): List of the primers and their nucleotide sequences used for ISSR procedure.

\begin{tabular}{|l|r|l|}
\hline No & Name & Sequence \\
\hline 1. & HB-08 & 5' GAG AGA GAG AGA GG 3' \\
\hline 2. & HB-11 & 5' GTG TGT GTG TGT CC 3' \\
\hline 3. & HB-12 & 5' CAC CAC CAC GC 3' \\
\hline 4. & HB-13 & 5' GAG GAG GAG GC 3' \\
\hline 5. & HB-15 & 5' GTG GTG GTG GC 3' \\
\hline
\end{tabular}

\section{RESULTS AND DISCUSSION}

The study included nine progenies (trees) as follows: one progeny (tree) for each open pollination of Nab El Gamal (T1) and El-Tarir (T2), two progenies for selfing of each of Nab-El Gamal (T3 and T4) and El-Tarir (T5 and T6) and three progenies for the hybrids between ElTahrir ${ }_{x}$ Nab El-Gamal ${ }^{\top}(\mathrm{T} 7, \mathrm{~T} 8$ and T9). Vegetative growth, fruit characteristics and molecular markers were investigated.

\subsection{Horticultural studies}

The differences between dates for blooming and fruit set of the nine progenies in the two successive seasons under study at 2012 and 2013 are presented in Table (2). Data revealed that the period of fruit set was the shortest in the progeny of selfing of Nab-El Gamal (T4) in the two seasons (46 days), while it was the longest for the selfed progeny of Nab-El Gamal (T3) for both seasons (57days) in the two seasons. The data showed that, although the ratio of male flowers to perfect flowers (hermaphrodite) was $1 / 5$ in the tree progeny of hybrid between ElTahrir 9 and Nab-El Gamal $\hat{\delta}$ (T7), the period of fruit set was 50 and 51 days in the two seasons, respectively. For the open pollination progeny of El-Tahrir, the ratio was $3 / 2$ for two successive seasons, while the fruit set period ranged between 47 and 43 days for two successive seasons. Singh et al. (1978) studied the behavior of flowering and sex expression in the some pomegranate cultivars. They reported that inflorescence developed from mixed buds situated terminally on the previous seasons growth as well as on old spurs.

Table (2) shows the initial date of vegetative growth in the nine different progenies of pomegranate during 2012 and 2013 seasons. The earliest was the hybrid between El-Tahriro and Nab El-Gamal $\delta$ (T9) (10 and 27 Jan) for both seasons, respectively. While, the latest one was Nab-El Gamal selefed (T4) (2 Feb), for both seasons.

Shoot growth of the nine progenies of pomegranate during 2012-2013 growing seasons is presented in Table (3). Data revealed that the selfed progeny of Nab-El Gamal (T3) exhibited significant superiority shoot length for both seasons ( 21.30 and $22.00 \mathrm{~cm}$, respectively). On the other hand, the selfed progeny of El-Tahrir (T6) exhibited the shortest shoot length (19.00 and $19.7 \mathrm{~cm}$,) for 2012 and 2013 seasons, respectively. Statistical analysis revealed that insignificant differences occurred in shoot diameter for all the studied progenies in the first season, while there were slight differences in the second one.

Statistical analysis revealed significant differences in the number of leaves per shoot for all progenies of different origins. The two selfed progenies of El-Tahrir (T5 and T6) gave the highest number of leaves ranging between 400.0 and 430.3 in the two seasons, while the lowest number was detected for the selfed progeny of Nab-El Gamal (T3) ranging between 337.0 and 355.3 , in the two seasons, respectively. In respect to the number of the internodes per shoot, the highest value was recorded by the selfed progeny of Nab-El Gamal (T4) 8.65 and 9.00 in the two seasons, respectively, the lowest (6.10 and 6.20) was recorded by the trees (T7 and T8) progenies of the hybrid between ElTahriro and Nab El-Gamal ${ }^{\widehat{O}}$ in the growing year 2013.

Concerning the leaf area, tree (T8) progeny of the hybrid El-Tahrir X Nab- El Gamal exhibited the highest values (6.033 and 5.767 $\mathrm{cm}^{2}$ ) for the two seasons, respectively, while the lowest value was recorded by the openpollinated progeny Nab-El Gamal (T1) of, (3.490 and $3.410 \mathrm{~cm}^{2}$ for both seasons, respectively.

Table (4), shows the percentage of fruit set, yield per tree and the number of fruits per tree 
Table (2): Dates of flowering and fruit set mean, fruit set period initial date of the vegetative growth and the ratio of male/ perfect flowers (hermaphrodite)of different progenies (open, self and hybrid) of pomegranate in 2012 and 2013 seasons.

\begin{tabular}{|c|c|c|c|c|c|c|c|c|c|c|c|c|c|c|c|}
\hline \multirow{3}{*}{$\begin{array}{l}\text { Tree } \\
\text { No. }\end{array}$} & \multirow{3}{*}{ Progeny } & \multicolumn{4}{|c|}{ Blooming date } & \multicolumn{4}{|c|}{ Fruit set } & \multirow{2}{*}{\multicolumn{2}{|c|}{$\begin{array}{c}\text { Initial date of } \\
\text { vegetative growth }\end{array}$}} & \multirow{2}{*}{\multicolumn{2}{|c|}{$\begin{array}{c}\text { Fruit set } \\
\text { period (day) }\end{array}$}} & \multirow{2}{*}{\multicolumn{2}{|c|}{$\begin{array}{c}\text { Male flowers / } \\
\text { Perfect Flowers } \\
\text { ( Ratio) }\end{array}$}} \\
\hline & & \multicolumn{2}{|c|}{ Initial } & \multicolumn{2}{|c|}{ End } & \multicolumn{2}{|c|}{ Initial } & \multicolumn{2}{|c|}{ End } & & & & & & \\
\hline & & 2012 & 2013 & 2012 & 2013 & 2012 & 2013 & 2012 & 2013 & 2012 & 2013 & 2012 & 2013 & 2012 & 2013 \\
\hline T1. & Nab-EI Gamal(O) & Mar.28 & Mar.30 & May17 & May22 & Mar.30 & Apr. 2 & May22 & May12 & Jan. 27 & Jan. 30 & 52 & 40 & $1 / 4$ & $2 / 3$ \\
\hline T2. & El-Tahrir $(O)$ & $\sim \sim 29$ & $\sim \sim 27$ & $\sim \sim 20$ & $\sim \sim 20$ & Apr.1 & $\sim \sim 4$ & $\sim \sim 28$ & $\sim \sim 17$ & $\sim \sim 29$ & Feb. 5 & 47 & 43 & $3 / 2$ & $3 / 2$ \\
\hline T3. & Nab-El Gamal(S) & $\sim \sim 29$ & $\sim \sim 29$ & $\sim \sim 20$ & $\sim \sim 20$ & $\sim \sim 1$ & $\sim \sim 1$ & $\sim \sim 28$ & $\sim \sim 28$ & $\sim \sim 29$ & Jan. 29 & 57 & 57 & $3 / 2$ & $3 / 2$ \\
\hline T4. & Nab-El Gamal (S) & $\sim \sim 30$ & $\sim \sim 30$ & $\sim \sim 17$ & $\sim \sim 17$ & $\sim \sim 3$ & $\sim \sim 3$ & $\sim \sim 19$ & $\sim \sim 19$ & Feb. 2 & Feb. 2 & 46 & 46 & $2 / 4$ & $2 / 4$ \\
\hline T5. & El-Tahrir (S) & $\sim \sim 28$ & $\sim \sim 25$ & $\sim \sim 17$ & $\sim \sim 10$ & Mar.30 & Mar.27 & $\sim \sim 22$ & $\sim \sim 20$ & Jan. 27 & Jan. 20 & 53 & 54 & $1 / 4$ & $2 / 5$ \\
\hline T6. & El-Tahrir (S) & $\sim \sim 28$ & $\sim \sim 25$ & $\sim \sim 17$ & $\sim \sim 10$ & $\sim \sim 30$ & $\sim \sim 27$ & $\sim \sim 22$ & $\sim \sim 20$ & $\sim \sim 27$ & $\sim \sim 20$ & 53 & 54 & $1 / 4$ & $2 / 5$ \\
\hline T8. & $\begin{array}{l}\text { El-Tahrir }{ }^{\rho} \times \text { Nab-El } \\
\text { Gamal }{ }^{\lambda}\end{array}$ & $\sim \sim 29$ & $\sim \sim 25$ & $\sim \sim 17$ & $\sim \sim 12$ & $\sim \sim 29$ & $\sim \sim 28$ & $\sim \sim 15$ & $\sim \sim 11$ & $\begin{array}{l}\sim 29 \\
\sim\end{array}$ & $\sim \sim 27$ & 47 & 44 & $1 / 4$ & $2 / 4$ \\
\hline T9. & $\begin{array}{l}\text { El-Tahrir }{ }^{\circ} \times \text { Nab-El } \\
\text { Gamal }{ }^{\lambda}\end{array}$ & $\sim \sim 15$ & $\sim \sim 25$ & $\begin{array}{c}\sim 23 \\
\end{array}$ & $\sim \sim 12$ & Apr.7 & $\begin{array}{l}\sim 29 \\
\end{array}$ & $\begin{array}{c}\sim 30 \\
\end{array}$ & $\sim \sim 11$ & $\sim \sim 10$ & $\sim \sim 27$ & 53 & 43 & $2 / 3$ & $2 / 4$ \\
\hline
\end{tabular}

(O) Progeny resulted from open pollination (trees No. 1 and 2 )

(S) Progeny resulted from self pollination (trees No. 3 to 6)

Hybrid between El-Tahrir $\odot \times$ Nab El-Gamal ${ }^{\gamma}($ trees No. 7 to 9)

Table (3): Means of vegetative growth traits of different progenies of pomegranate in 2012 and 2013 seasons.

\begin{tabular}{|c|c|c|c|c|c|c|c|c|c|c|c|}
\hline \multirow{2}{*}{$\begin{array}{l}\text { Tree } \\
\text { No. }\end{array}$} & \multirow[t]{2}{*}{ Progeny } & \multicolumn{2}{|c|}{$\begin{array}{c}\text { Mean of shoot length } \\
(\mathrm{cm})\end{array}$} & \multicolumn{2}{|c|}{$\begin{array}{l}\text { Mean of shoot } \\
\text { diameter }(\mathbf{c m})\end{array}$} & \multicolumn{2}{|c|}{ No. of leaves per shoot } & \multicolumn{2}{|c|}{$\begin{array}{c}\text { No. of internodes per } \\
\text { shoot }\end{array}$} & \multicolumn{2}{|c|}{ Leaf Area $\left(\mathrm{cm}^{2}\right)$} \\
\hline & & 2012 & 2013 & 2012 & 2013 & 2012 & 2013 & 2012 & 2013 & 2012 & 2013 \\
\hline T1. & Nab-El Gamal(O) & $20.00 \mathrm{ab}$ & 21.00 a-c & $3.30 \mathrm{a}$ & $3.23 \mathrm{~b}$ & 410.0 ab & $432.0 \mathrm{a}$ & $8.63 \mathrm{a}$ & $8.20 \mathrm{c}$ & $3.490 \mathrm{c}$ & $3.410 \mathrm{e}$ \\
\hline T2. & El-Tahrir (O) & 20.60 ab & $20.00 \mathrm{~cd}$ & $3.27 \mathrm{a}$ & $3.30 \mathrm{ab}$ & $390.0 \mathrm{~b}$ & $360.3 \mathrm{c}$ & $8.13 \mathrm{bc}$ & $8.50 \mathrm{~b}$ & $4.400 \mathrm{~b}$ & $4.950 \mathrm{~b}$ \\
\hline T3. & Nab-El Gamal (S) & $21.30 \mathrm{a}$ & $22.00 \mathrm{a}$ & $3.27 \mathbf{a}$ & $3.30 \mathrm{ab}$ & $337.0 \mathrm{c}$ & $355.3 \mathrm{c}$ & $8.53 \mathrm{ab}$ & $9.13 \mathrm{a}$ & $4.597 \mathrm{~b}$ & $5.123 \mathrm{~b}$ \\
\hline T4. & Nab-El Gamal (S) & $21.70 \mathrm{a}$ & $21.33 \mathrm{ab}$ & $3.30 \mathrm{a}$ & $3.27 \mathrm{~b}$ & 413.0 ab & $336.0 \mathrm{c}$ & $8.65 \mathrm{a}$ & $9.00 \mathrm{a}$ & $4.523 \mathrm{~b}$ & $3.723 \mathrm{~d}$ \\
\hline T5. & El-Tahrir (S) & $18.70 \mathrm{~b}$ & $20.60 b-d$ & $3.23 \mathrm{a}$ & $3.23 \mathrm{~b}$ & $418.0 \mathrm{a}$ & $400.0 \mathrm{~b}$ & $7.42 \mathrm{~d}$ & $8.50 \mathrm{~b}$ & $4.100 \mathrm{~b}$ & $4.377 \mathrm{c}$ \\
\hline T6. & El-Tahrir $\left(\mathbf{S}_{2}\right.$ & $19.00 \mathrm{~b}$ & $19.7 \mathrm{~d}$ & $3.30 \mathrm{a}$ & $3.23 \mathrm{~b}$ & $425.3 \mathrm{a}$ & $430.3 \mathrm{a}$ & $7.80 \mathrm{~cd}$ & $8.23 \mathrm{c}$ & $4.203 \mathrm{~b}$ & $3.987 \mathrm{~d}$ \\
\hline T7. & $\begin{array}{l}\text { El-Tahrir } \bigcirc \times \text { ab-El } \\
\text { Gamal } 1\end{array}$ & $20.00 \mathrm{ab}$ & $20.00 \mathrm{~cd}$ & $3.30 \mathrm{a}$ & $3.30 \mathrm{ab}$ & 388.7 b & $335.0 \mathrm{c}$ & $8.70 \mathrm{a}$ & $6.10 \mathrm{e}$ & $4.500 \mathrm{~b}$ & $4.307 \mathrm{c}$ \\
\hline T8. & $\begin{array}{l}\text { El-Tahrir }{ }^{\circ} \times \text { Nab-El } \\
\text { Gamal }{ }^{\lambda}\end{array}$ & $20.00 \mathrm{ab}$ & 21.27 ab & $3.37 \mathrm{a}$ & $3.27 \mathrm{~b}$ & $389.0 \mathrm{~b}$ & $334.7 \mathrm{c}$ & $8.00 \mathrm{c}$ & $6.20 \mathrm{e}$ & $6.033 \mathrm{a}$ & 5.767 a \\
\hline T9. & 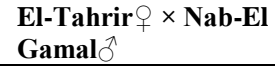 & 20.70 ab & $20.33 \mathrm{~b}-\mathrm{d}$ & $3.30 \mathrm{a}$ & $3.40 \mathrm{a}$ & $359.0 \mathrm{c}$ & $364.3 \mathrm{c}$ & $6.83 \mathrm{e}$ & $7.80 \mathrm{~d}$ & $6.267 \mathrm{a}$ & $2.527 \mathrm{f}$ \\
\hline
\end{tabular}

(O) Progeny resulted from open pollination (trees No. 1 and 2 )

(S) Progeny resulted from self pollination (trees No. to 6)

Hybrid between El-Tahrir $\odot \times$ Nab El-Gamal ${ }^{\lambda}($ trees No. 7 to 9)

Means followed by the same letter within the same column are not significantly different $P=0.05$ 
for all progenies under investigation. The highest percentage of fruit set was recorded by selfed progeny of El-Tarir (T5) and the hybrid progeny (T8). On the other hand, open-pollination progeny of Nab El-Gamal (T1) exhibited the lowest percentage which reached to $17.15 \%$. As regards yield/tree, the progenies resulted from self pollination of Nab-El Gamal tree (T3) and the hybrid between El-Tarir X Nab-El Gamal gave the highest yield/tree ranging between 21.75 and $22.50 \mathrm{Kg} /$ tree. In contrast, the open- the greater percentage of fruit set was observed by hand pollination and pollination under natural conditions (open-pollination). Bist et al. (1994) reported a great variation in fruit set of some promising selections of wild pomegranate. Moreover, Khalil et al. (1985) and Abou ElKhashab et al. (2005) studied the vegetative growth of some selections of some cultivars of pomegranate under a new reclaimed region and stated that Nab El Gamal cultivar gave the best fruit characteristics and yield.

Table (4): Percentage of fruit set, yield per tree $(\mathrm{Kg})$ and the number of fruits per tree of different progenies of pomegranate during the two seasons.

\begin{tabular}{|c|c|c|c|c|}
\hline $\begin{array}{l}\text { Tree } \\
\text { No. }\end{array}$ & Progeny & Fruit set \% & Yield / tree $(\mathrm{Kg})$ & No. of fruits /tree \\
\hline T1. & Nab-El Gamal(O) & $17.15 \mathrm{~d}$ & $11.25 \mathrm{~d}$ & 56.000 ab \\
\hline T2. & El-Tahrir $(0)$ & $18.70 \mathrm{~cd}$ & $13.50 \mathrm{~cd}$ & $38.825 \mathrm{~b}$ \\
\hline T3. & Nab-El Gamal (S) & $19.30 \mathrm{~b}-\mathrm{d}$ & $22.50 \mathrm{a}$ & 51.090 ab \\
\hline T4. & Nab-El Gamal (S) & 20.25 b-d & $21.75 \mathrm{a}$ & $56.420 \mathrm{ab}$ \\
\hline T5. & El-Tahrir (S) & 25.65 a & $12.75 \mathrm{ab}$ & $61.900 \mathrm{ab}$ \\
\hline T6. & El-Tahrir (S) & $23.90 \mathrm{ab}$ & $17.50 \mathrm{ab}$ & 70.940 a \\
\hline T7. & El-Tahrir ${ }^{\circ} \times$ Nab-EI Gamal ${ }^{\wedge}$ & 23.05 a-c & $15.25 \mathrm{ab}$ & $63.690 \mathrm{ab}$ \\
\hline T8. & El-Tahrir ${ }^{\circ} \times$ Nab-EI Gamal ${ }^{\wedge}$ & 25.15 a & $16.00 \mathrm{ab}$ & $52.335 \mathrm{ab}$ \\
\hline T9. & El-Tahrir $\bigcirc \times$ Nab-EI Gamal ${ }^{\wedge}$ & 23.25 a-c & $22.50 \mathrm{a}$ & $63.420 \mathrm{ab}$ \\
\hline
\end{tabular}

(O) Progeny resulted from open pollination (trees No. 1 and 2)

(S) Progeny resulted from self pollination (trees No. 3 to 6 )

Hybrid between El-Tahrir $+\times$ Nab El-Gamal $\widehat{\jmath}$ (trees No. 7 to 9)

Means followed by the same letter within the same column are not significantly different $\mathrm{P}=0.05$

pollination progeny of Nab El-Gamal (T1) gave the lowest yield/tree $(11.25 \mathrm{Kg})$.

Concerning the number of fruits/tree, the highest value was recorded by selfed progeny of El-Tarir (T6), of 70.940, while the lowest value of 38.825 was achived by the open pollination progeny of El-Tarir (T2). Nath and Randhawa (1959b) studied the fruit set and seed formation of some pomegranate cultivars and reported that
Table (5) showed significant differences in the vegetative growth of nine progenies resulted from different origins of pomegranate. Statistical analysis revealed that significant differences occurred in tree height. El-Tarir selfed progenies (trees No) and the hybrid progeny of El-Tarir X Nab-El Gamal (T8) gave the highest value ranging from 3.4 to $3.60 \mathrm{~m}$ respectively, while the lowest value was $2.33 \mathrm{~m}$ for the open progeny

Table (5): Tree height, trunk circumference and chlorophyll A, B and Caroten in the leaves of different progenies of pomegranate during two seasons

\begin{tabular}{|c|c|c|c|c|c|c|}
\hline $\begin{array}{l}\text { Tree } \\
\text { No. }\end{array}$ & Progeny & $\begin{array}{l}\text { Tree height } \\
\text { (m) }\end{array}$ & $\begin{array}{c}\text { Trunk } \\
\text { circumference } \\
\text { (cm) }\end{array}$ & $\begin{array}{c}\text { Chlorophyll A } \\
(\mathrm{mg} / \mathrm{g})\end{array}$ & $\begin{array}{c}\text { Chlorophyll } \\
\text { B(mg/g) }\end{array}$ & Caroten $(\mathrm{mg} / \mathrm{g})$ \\
\hline T1. & Nab-El Gamal(O) & $2.3250 \mathrm{e}$ & $13.2500 \mathrm{~b}$ & $1.1400 \mathrm{ab}$ & 0.3895 c & $0.7430 \mathrm{f}$ \\
\hline T2. & El-Tahrir (O) & $2.6000 \mathrm{de}$ & $17.7500 \mathrm{ab}$ & $1.2130 \mathrm{ab}$ & 0.4565 bc & $0.9120 \mathrm{c}$ \\
\hline T3. & Nab-EI Gamal (S) & $2.6250 \mathrm{de}$ & $19.5000 \mathrm{a}$ & $1.3370 \mathrm{a}$ & 0.5870 b & $1.0360 \mathrm{~b}$ \\
\hline T4. & Nab-EI Gamal (S) & $2.9000 \mathrm{~cd}$ & $16.5000 \mathrm{ab}$ & $1.1805 a b$ & 0.4035 bc & $0.8405 \mathrm{~d}$ \\
\hline T5. & El-Tahrir (S) & 3.0750 bc & 20.5000 a & $1.0900 \mathrm{ab}$ & 0.3765 c & $0.7380 \mathrm{f}$ \\
\hline T6. & El-Tahrir (S) & $3.4000 \mathrm{ab}$ & 20.0000 a & $1.1030 \mathrm{ab}$ & $0.3900 \mathrm{c}$ & 0.7705 e \\
\hline T7. & $\begin{array}{l}\text { El-Tahrir }{ }_{+} \times \text {Nab- } \\
\text { El Gamal }{ }^{\lambda}\end{array}$ & $2.8750 \mathrm{~cd}$ & $17.5000 \mathrm{ab}$ & $1.5925 \mathrm{a}$ & 0.5350 bc & $1.0170 \mathrm{~b}$ \\
\hline T8. & $\begin{array}{l}\text { El-Tahrir }{ }_{+} \times \text {Nab- } \\
\text { El Gamal }\end{array}$ & $3.6000 \mathrm{a}$ & $17.5000 \mathrm{ab}$ & $0.6210 \mathrm{~b}$ & $1.3100 \mathrm{a}$ & $1.2940 \mathrm{a}$ \\
\hline T9. & $\begin{array}{l}\text { El-Tahrir } \odot \times \text { Nab- } \\
\text { El Gamal }{ }^{\lambda}\end{array}$ & $3.4000 \mathrm{ab}$ & $20.5000 \mathrm{a}$ & $1.1985 \mathrm{ab}$ & 0.4645 bc & $0.8520 \mathrm{~d}$ \\
\hline
\end{tabular}

(O) Progeny resulted from open pollination (trees No. 1 and 2)

(S) Progeny resulted from self pollination (trees No. 3 to 6)

Hybrid between El-Tahrir $q \times$ Nab El-Gamal ${ }^{\lambda}($ trees No. 7 to 9)

Means followed by the same letter within the same column are not significantly different $(\mathbf{P}=\mathbf{0 . 0 5})$ 
of Nab El-Gamal (T1). Significant differences were recorded in trunk circumference, ranging from $13.25 \mathrm{~cm}$ for open pollination progeny of Nab-El Gamal (T1) to $20.50 \mathrm{~cm}$ for El-Tarir selfed progeny (T5) and the studied hybrid (T9).

Considerable variation in chlorophyll $\mathrm{A}$ and $\mathrm{B}$ and carotene in the leaves was observed among progenies in Table (5). The highest value of chlorophyll A $(1.5925 \mathrm{mg} / \mathrm{g})$ was recorded by the hybrid tree (T7). Meanwhile, the tree (T8) of the hybrid (El-Tarir xNab-El Gamal) gave the lowest value of chlorophyll A $(0.6210 \mathrm{mg} / \mathrm{g})$. With respect to chlorophyll $\mathrm{B}$ and carotene, the highest values of chlorophyll $\mathrm{B}$ and carotene $(1.3100$ and $1.2940 \mathrm{mg} / \mathrm{g}$, respectively) were recorded by hybrid EL-Tarir X Nab- El Gamal tree (T8). It can be concluded that genetic changes in the progenies had an effect on the quantity of chlorophyll A and B and carotene. These results are in agreement with those reported by Sukran et al. (1998).

Table (6) shows the characteristics of mature fruits produced by the nine studied progenies. Statistical analysis revealed that highly significant differences were recorded in fruit weight and size. In both seasons, Nab-El Gamal selfed trees T3 and T4 (Fig.1) recorded the highest values, while El-Tahrir open-pollination progeny recorded the highest value in the first season only. In contrast, the open pollinated progeny of Nab-El Gamal, gave the lowest fruit weight in the first season $(100.167 \mathrm{~g})$, while this tree had the highest value in the second season.

Regarding the fruit size, the tree (T3) of selfed progeny of Nab-El Gamal gave the highest value $\left(387.0\right.$ and $466.7 \mathrm{~cm}^{3}$ for the two seasons, respectively. The lowest value was recorded by open pollination progeny of Nab-El Gamal (T1) $\left(95.00 \mathrm{~cm}^{3}\right)$, in 2012 .

In respect to fruit diameter, significant differences were recorded between the different progenies; the highest values of fruit diameter, and fruit length were recorded by El-Tarir (T2) and selfed tree of Nab-El Gamal (T3), in the first season, while in the second season the same tree gave the highest value for fruit diameter and fruit length. On the other hand, the openpollination progeny Nab-El Gamal (T1) gave the lowest fruit diameter $(5.9 \mathrm{~cm})$ and fruit length $(5.2 \mathrm{~cm})$ in first season, while El-Tarir selfed progeny (T6) gave the lowest fruit diameter $(7.67 \mathrm{~cm})$ and fruit length $(6.97 \mathrm{~cm})$ in second season. Regarding the fruit circumference, the highest value by El-Tahrir open-pollination progeny (T2) $(30.07 \mathrm{~cm})$, while the lowest value was recorded by Nab-El Gamal open-pollination progeny $\mathrm{T} 1(14.23 \mathrm{~cm})$, in the first season. In the second season, Nab-El Gamal selfed progeny (T3) gave the highest value of $(31.40 \mathrm{~cm})$; while the lowest value $(23.50 \mathrm{~cm})$ was achived by the tree T6 of El-Tarir (selfed). In respect to fruit room number, five progenies (T1, T2, T4, T7 and T9) exhibited the highest values of room number (6.00), in first season. While in the second season, six progenies (T1, T3, T4, T6, T7 and T8) showed high number of rooms ranging from 6.00 to 6.67. Levin (1990) studied the mean performance of hybrids resulting from crossing of 53 maternal varieties and 13 pollen parents, in pomegranate. He reported that dwarfing habit is a desirable character of pomegranate tree for mechanical and easy harvesting in particular growing conditions.

Table (7) shows the fruit chemical characters of the nine progenies. Significant differences existed for percentage of T.S.S and total acidity in the two seasons 2012 and 2013. Regarding T.S.S./Acidity ratio, in the first season, El-Tahrir open-pollination (T2) progeny gave the highest ratio of T.S.S /Acidity (24.93), while the lowest was recorded for the tree (T8) of hybrid (ElTahrir X Nab-El Gamal) (17.66).In the second season, all progenies gave high ratio comparing with the first season. The highest value was recorded by Nab El Gamal selfed progeny (T4) and El-Tahrir selfed tree (T5) and the hybrid tree (T7) of (El-Tahrir X Nab-El Gamal). For the percentage of grains, the selfed progenies of ElTahrir (T5 and T6) showed the highest values, in both seasons, ranging between 75.50 and $59.70 \%$. The lowest percentage was recorded by Nab-El Gamal open-pollination progeny (T1) and the hybrid progeny of El-Tarir x Nab-El Gamal (T9), in the first season. In the second season, the selfed progeny of Nab-El Gamal (T4) exhibited the lowest value (43.23\%).

The number of grains in $100 \mathrm{~g}$ for all progenies is presented in Table (7). Nab-El Gamal open pollination progeny (T1) showed the highest value; it ranged between 383.0 and 412.0 in the two seasons, respectively. The lowest value for the tree T3 (Nab-El Gamal selfed) was 206.0 and 265.8, in the two seasons, respectively. For percentage of juice, significant differences were recorded between the different progenies. El-Tahrir selfed progeny (tree T6) gave the highest value (38.10 and $38.5 \%$ ) in the two seasons, while the lowest value was found for the hybrid ( El-Tahrir X Nab-El Gamal) (tree T9 Table 7), which gave 21.00 and $18.03 \%$ in 
Table (6): Fruit physical characteristics of different progenies(open, self pollination) and hybrid) of pomegranate, in 2012 and 2013 seasons.

\begin{tabular}{|c|c|c|c|c|c|c|c|c|c|c|c|c|c|c|}
\hline \multirow{2}{*}{$\begin{array}{l}\text { Tree } \\
\text { No. }\end{array}$} & \multirow{2}{*}{ Progeny } & \multicolumn{2}{|c|}{ Fruit Weight (gm) } & \multicolumn{2}{|c|}{ Fruit size $\left(\mathrm{cm}^{2}\right)$} & \multicolumn{2}{|c|}{ Fruit diameter (cm) } & \multicolumn{2}{|c|}{ Fruit length (cm) } & \multicolumn{2}{|c|}{ Fruit circumference $(\mathbf{c m})$} & \multicolumn{2}{|c|}{ Fruit room No. } & \multirow{2}{*}{$\begin{array}{c}\begin{array}{c}\text { Color of } \\
\text { fruit }\end{array} \\
\text { Two } \\
\text { seasons }\end{array}$} \\
\hline & & 2012 & 2013 & 2012 & 2013 & 2012 & 2013 & 2012 & 2013 & 2012 & 2013 & 2012 & 2013 & \\
\hline T1. & Nab-EI Gamal(O) & $100.167 f$ & $386.100 a$ & $95.000 \mathrm{f}$ & $359.667 \mathrm{c}$ & $5.90 \mathrm{e}$ & $8.57 \mathrm{c}$ & $5.20 \mathrm{e}$ & $8.33 \mathrm{a}-\mathrm{c}$ & $14.23 \mathrm{f}$ & $29.00 \mathrm{~b}$ & $6.00 \mathrm{a}$ & $6.67 \mathrm{a}$ & $\begin{array}{l}\text { Reddish } \\
\text { Yellow }\end{array}$ \\
\hline T2. & El-Tahrir (O) & $440.100 a$ & $292.667 \mathrm{c}$ & 363.000a & 291.333d & $9.60 \mathrm{a}$ & $8.47 \mathrm{~cd}$ & $8.30 \mathrm{a}$ & 7.97 b-c & 30.07 a & $26.43 \mathrm{~d}$ & $6.00 \mathrm{a}$ & $5.67 \mathrm{~b}-\mathrm{d}$ & $\begin{array}{l}\text { Reddish } \\
\text { Yellow }\end{array}$ \\
\hline T3. & Nab-El Gamal (S) & $400.000 a$ & $479.000 a$ & $387.000 \mathrm{a}$ & $466.667 a$ & 9.371 a & $9.83 \mathrm{a}$ & $8.03 \mathrm{a}$ & $8.80 \mathrm{a}$ & $29.50 \mathrm{a}$ & $31.40 \mathrm{a}$ & $5.33 \mathrm{ab}$ & $6.00 \mathrm{a}-\mathrm{c}$ & $\begin{array}{l}\text { Greenish } \\
\text { Yellow }\end{array}$ \\
\hline T4. & Nab-El Gamal (S) & $356.633 a$ & 424.000a & $327.000 b$ & $410.000 b$ & $8.77 \mathrm{~b}$ & $9.50 \mathrm{ab}$ & 8.07 a & $8.50 \mathrm{ab}$ & 24.73 b & $31.00 \mathrm{a}$ & $6.00 \mathrm{a}$ & $6.33 \mathrm{ab}$ & $\begin{array}{l}\text { Greenish } \\
\text { Yellow }\end{array}$ \\
\hline T5. & El-Tahrir (S) & $160.333 \mathrm{e}$ & 258.000d & $155.000 \mathrm{e}$ & 243.000e & $6.20 \mathrm{e}$ & $8.03 \mathrm{~d}-\mathrm{f}$ & $5.60 \mathrm{~d}$ & $7.70 \mathrm{c}$ & $19.03 \mathrm{e}$ & $25.33 \mathrm{e}$ & $4.67 \mathrm{~b}$ & $5.00 \mathrm{~d}$ & $\begin{array}{c}\text { Red } \\
\text { Yellow }\end{array}$ \\
\hline T6. & El-Tahrir (S) & $265.000 \mathrm{~b}$ & $234.333 \mathrm{e}$ & 244.333c & $226.000 \mathrm{e}$ & $8.57 \mathrm{~b}$ & 7.67 ef & $7.67 \mathrm{a}$ & $6.97 \mathrm{~d}$ & $27.03 \mathrm{a}$ & $23.50 \mathrm{f}$ & $4.67 \mathrm{~b}$ & $6.00 \mathrm{a}-\mathrm{c}$ & $\begin{array}{c}\text { Red } \\
\text { Yellow }\end{array}$ \\
\hline T7. & $\begin{array}{l}\text { El-Tahrir } 9 \times \text { Nab-El } \\
\text { Gamal }{ }^{\lambda}\end{array}$ & $210.000 d$ & $264.533 d$ & $194.333 d$ & 246.333e & $7.00 \mathrm{~d}$ & $8.00 \mathrm{f}$ & $6.23 \mathrm{c}$ & $6.90 \mathrm{~d}$ & $23.03 \mathrm{~d}$ & $26.17 \mathrm{~d}$ & $6.00 \mathrm{a}$ & $6.00 \mathrm{a}-\mathrm{c}$ & $\begin{array}{l}\text { Reddish } \\
\text { Yellow }\end{array}$ \\
\hline T8. & $\begin{array}{l}\text { El-Tahrir }{ }_{+} \times \text {Nab-El } \\
\text { Gamal }^{\lambda}\end{array}$ & $240.700 c$ & $356.933 b$ & $222.333 c$ & $359.667 \mathrm{c}$ & $7.30 \mathrm{~d}$ & $9.17 \mathrm{~b}$ & $7.00 \mathrm{~b}$ & 8.03 a-c & 24.17 c & 29.47 b & $5.33 \mathrm{ab}$ & $6.00 \mathrm{a}-\mathrm{c}$ & $\begin{array}{c}\text { Reddish } \\
\text { Yellow } \\
\end{array}$ \\
\hline T9. & $\begin{array}{l}\text { El-Tahrir }{ }_{+} \times \text {Nab-EI } \\
\text { Gamal }{ }^{\lambda}\end{array}$ & $341.000 a$ & 366.000ab & $314.667 b$ & $310.667 d$ & $8.20 \mathrm{c}$ & 8.37 c-e & $7.03 \mathrm{~b}$ & 8.27 a-c & 27.47 a & $27.57 \mathrm{c}$ & $6.00 \mathrm{a}$ & $5.33 \mathrm{~cd}$ & $\begin{array}{l}\text { Reddish } \\
\text { Yellow } \\
\end{array}$ \\
\hline
\end{tabular}

(O) Progeny resulted from open pollination (trees No. 1 and 2 )

(S) Progeny resulted from self pollination (trees No. 3 to 6)

Hybrid between El-Tahrir $\odot \times$ Nab El-Gamal ${ }^{\top}($ trees No. 7 to 9)

Means followed by the same letter within the same column are not significantly different $P=0.05$

Table (7): Fruit chemical characteristics of different progenies (open, self pollination and hybrid) in 2012 and 2013 season.

\begin{tabular}{|c|c|c|c|c|c|c|c|c|c|c|c|c|c|c|}
\hline \multirow[t]{2}{*}{$\begin{array}{c}\text { Tree } \\
\text { no. }\end{array}$} & \multirow[t]{2}{*}{ Progeny } & \multicolumn{2}{|c|}{ T.S.S \% } & \multicolumn{2}{|c|}{ Acidity \% } & \multicolumn{2}{|c|}{$\begin{array}{c}\text { T.S.S/ } \\
\text { acidity Ratio }\end{array}$} & \multicolumn{2}{|c|}{$\begin{array}{l}\text { Percentage of } \\
\text { grains } \%\end{array}$} & \multicolumn{2}{|c|}{ No. of grains in $100 \mathrm{~g}$} & \multicolumn{2}{|c|}{$\begin{array}{l}\text { Percentage } \\
\text { of juice \% }\end{array}$} & \multirow{2}{*}{$\begin{array}{c}\text { Color of grains } \\
\text { Two seasons }\end{array}$} \\
\hline & & 2012 & 2013 & 2012 & 2013 & 2012 & 2013 & 2012 & 2013 & 2012 & 2013 & 2012 & 2013 & \\
\hline T1. & Nab-El Gamal(O) & $9.17 \mathrm{c}$ & $12.33 \mathrm{~cd}$ & $0.509 \mathrm{~b}$ & $0.482 \mathrm{c}$ & $18.33 \mathrm{~d}$ & $25.64 d$ & $44.40 \mathrm{e}$ & 50.70 bc & 383.0 a & $412.0 \mathrm{a}$ & 29.10 bc & $28.40 \mathrm{~b}$ & Light Pink \\
\hline T2. & El-Tahrir $(\mathbf{O})$ & $12.00 \mathrm{a}$ & $14.00 \mathrm{~b}$ & $0.482 \mathrm{~b}$ & $0.525 \mathrm{~b}$ & 24.93 a & $26.66 \mathrm{~cd}$ & $69.20 \mathrm{~b}$ & 59.97 a & 214.2 de & 275.7 bc & 32.00 bc & $38.80 \mathrm{a}$ & Light Pink \\
\hline T3. & Nab-El Gamal (S) & $9.67 \mathrm{bc}$ & $10.50 \mathrm{e}$ & $0.405 \mathrm{c}$ & $0.369 \mathrm{~d}$ & 24.15 ab & $26.98 \mathrm{~cd}$ & $49.90 \mathrm{~d}$ & $46.57 \mathrm{~b}-\mathrm{d}$ & $206.0 \mathrm{e}$ & $265.8 \mathrm{c}$ & $28.90 \mathrm{bc}$ & $27.30 \mathrm{~b}$ & Light Pink \\
\hline T4. & Nab-El Gamal (S) & 10.33 bc & $12.93 \mathrm{c}$ & $0.488 \mathrm{~b}$ & $0.405 \mathrm{~d}$ & $20.60 \mathrm{~b}-\mathrm{d}$ & $31.93 \mathrm{a}$ & $51.00 \mathrm{~d}$ & $43.23 \mathrm{~d}$ & $240.2 \mathrm{~cd}$ & 330.2 bc & 30.67 bc & $31.07 \mathbf{a}$ & Pink \\
\hline T5. & El-Tahrir $(\mathbf{S})$ & 10.17 bc & $15.33 \mathrm{a}$ & $0.520 \mathrm{~b}$ & $0.481 \mathrm{c}$ & $19.59 \mathrm{~cd}$ & $31.90 \mathrm{a}$ & 79.27 a & $51.30 \mathrm{~b}$ & $291.0 \mathrm{~b}$ & $342.7 \mathrm{~b}$ & $32.97 \mathrm{~b}$ & $35.20 \mathrm{a}$ & Light Pink \\
\hline T6. & El-Tahrir (S) & $12.00 \mathrm{a}$ & $14.33 \mathrm{ab}$ & $0.509 \mathrm{~b}$ & $0.492 \mathrm{bc}$ & 23.65 ab & 29.18 a-c & $75.50 \mathrm{a}$ & 59.70 a & $297.7 \mathrm{~b}$ & 332.7 bc & 38.10 a & $38.50 \mathrm{a}$ & Light Pink \\
\hline T7. & $\begin{array}{l}\text { El-Tahrir }+\times \text { Nab-El } \\
{\text { Gamal }{ }^{\lambda}}\end{array}$ & $12.00 \mathrm{a}$ & $12.00 \mathrm{~d}$ & $0.533 \mathrm{~b}$ & $0.376 \mathrm{~d}$ & 22.57 a-c & $31.96 \mathrm{a}$ & 57.07 c & $51.42 \mathrm{~b}$ & $250.0 \mathrm{c}$ & 310.8 bc & $28.00 \mathrm{c}$ & $23.80 \mathrm{c}$ & Dark Pink \\
\hline T8. & $\begin{array}{l}\text { El-Tahrir }+\times \text { Nab-El } \\
{\text { Gamal }{ }^{\lambda}}^{-}\end{array}$ & $11.17 \mathbf{a b}$ & $16.83 \mathrm{a}$ & $0.632 \mathrm{a}$ & $0.600 \mathrm{a}$ & $17.66 \mathrm{~d}$ & 28.05 b-d & $58.30 \mathrm{c}$ & $60.03 \mathrm{a}$ & 214.1 de & 320.0 bc & $23.00 \mathrm{~d}$ & $21.90 \mathrm{~d}$ & Light Pink \\
\hline T9. & $\begin{array}{l}\text { El-Tahrir }{ }^{\circ} \times \text { Nab-El } \\
\text { Gamal }^{\lambda}\end{array}$ & $9.17 \mathrm{c}$ & $15.00 \mathrm{a}$ & $0.482 \mathrm{~b}$ & 0.502 bc & $19.08 \mathrm{~cd}$ & 29.86 ab & $41.00 \mathrm{e}$ & $45.80 \mathrm{~cd}$ & 214.1 de & 287.4 bc & $21.00 \mathrm{~d}$ & $18.03 \mathrm{e}$ & Light Pink \\
\hline
\end{tabular}

(O) Progeny resulted from open pollination (trees No. 1 and 2)

(S) Progeny resulted from self pollination (trees No. 3 to 6 )

Hybrid between El-Tahrir $q \times$ Nab El-Gamal ${ }^{7}($ trees No. 7 to 9 )

Means followed bv the same letter within the same column are not significantlv different $P=0.05$ 
the two seasons, respectively. The table (6 and 7) presents the color of the fruit and the color of grains for different progenies. The tree $\mathrm{T} 9$ of hybrid (El-Tahrir X Nab-El Gamal) gave a good color (dark pink) for grains in the two seasons (Fig. 2).

Mir et al. (2007a and b) observed a high range of variability in pomegranate for fruit weight, volume, number of seeds and fruit color. Also, Varasteh et al. (2009) found a great variation in the important fruit characteristics of five commercial cultivars in Iran. Shulman et al. (1984), studied the growth curve of fruits, especially juice and T.S.S content, which increased continuously during maturation while acidity decreased.

\subsection{Genetic studies}

\subsubsection{Polymorphism detected by ISSR marker}

Five ISSR primers were tested with the DNA of nine progenies resulting from open and self pollination of Nab-El Gamal and El-Tahrir cultivars and the resulted hybrids between them (Fig.3). These primers produced multiple band profile which ranged from 8 to 15 amplicon (Table 8). The total number of amplicons amplified by the five primers was 57 with an average of 11.4/primer. The number of polymorphic bands ranged from 4 (HB-13) to 14 (HB-08), representing a percentage of polymorphism ranging from $50 \%$ (HB-12 and
El-Tahrir cultivar revealed an intermediate value of genetic similarity between the open pollinated progeny and the two self pollinated progenies (0.55 and 0.7, respectively). However, the genetic similarity between the two self pollinated progenies of El-Tahrir was 0.92.

Regarding the three tested hybrid progenies, it was noted that hybrid (T7) was close to NabEl Gamal and the farthest from El-Tahrir. Hybrid (T7) recorded genetic similarity with Nab-El Gamal ranging from 0.41 to 0.80 ; meanwhile, it ranged from 0.04 to 0.20 with ElTahrir. On the other hand, hybrid T8 showed a lower genetic similarity with El-Tahrir progenies (open, selfed T5\&T6) $(0.05,0.30$ and 0.11, respectively). The same observation was found with hybrid T9, it was closer to Nab-El Gamal of the values $(0.69,0.21$ and 0.60$)$ for (open, and self pollination $\mathrm{T} 1, \mathrm{~T} 3$ and $\mathrm{T} 4$, respectively), compared to El-Tahrir progenies (open, selfed $\mathrm{T} 2$, T5 and T6) of the values $(0.41,0.16$ and 0.27 , respectively). Genetic similarity value was very low among the three tested hybrid progenies of (El-Tahrir X Nab-El Gamal), which was zero between hybrids $1 \& 3$ and 0.06 between hybrid T8 \& T9. These variations observed in genetic similarity could be attributed to the effect of pollen grains source on the genetic structure of the resulted progenies.

Table (8): Polymorphism and its percentage as detected by ISSR marker.

\begin{tabular}{|c|c|c|c|c|}
\hline Primer & $\begin{array}{c}\text { Total No. } \\
\text { of amplicons }\end{array}$ & $\begin{array}{c}\text { Monomorphic } \\
\text { amplicons }\end{array}$ & $\begin{array}{c}\text { Polymorphism } \\
\text { amplicons }\end{array}$ & $\begin{array}{c}\text { Percentage of } \\
\text { polymorphism }\end{array}$ \\
\hline HB-08 & 15 & 1 & 14 & 93.3 \\
\hline HB-11 & 8 & 1 & 7 & 87.5 \\
\hline HB-12 & 14 & 7 & 7 & 50.0 \\
\hline HB-13 & 8 & 4 & 4 & 50.0 \\
\hline HB-15 & 12 & 5 & 7 & 58.3 \\
\hline Total & $\mathbf{5 7}$ & $\mathbf{1 8}$ & $\mathbf{3 9}$ & $\mathbf{6 7 . 8 2}$ \\
\hline Average & $\mathbf{1 1 . 4}$ & $\mathbf{3 . 6}$ & $\mathbf{7 . 8}$ & \\
\hline
\end{tabular}

HB-13) to $93.3 \%$ (HB-08). The size of the amplified bands varied according to the used primers, it ranged from $115 \mathrm{bp}$ to $128 \mathrm{bp}$.

\subsubsection{Genetic similarity}

The genetic similarity ranged from zero (between hybrid 1 and hybrid 2) to 1 (between the two genotypes of Nab-El Gamal self pollinated). A high value of genetic similarity was observed between Nab-El Gamal (open pollinated) and each of Nab-El Gamal (selfed T3 and T4) which reached 0.81 and 0.75 , respectively (Table 9).

\subsubsection{Cluster analysis}

The dendrogram obtained from UPGMA cluster analysis of the genetic distances (Fig 4) revealed that all of El-Tahrir progenies were separated in one cluster either for self-or open pollination progenies. Whereas, the second cluster consisted of the self and open pollination progenies of Nab-El GamaL. The second subcluster was also divided into two groups, where the hybrid T9 was separated in one of these groups.

The second group was divided in two subgroups, one of them consisted of the two self 


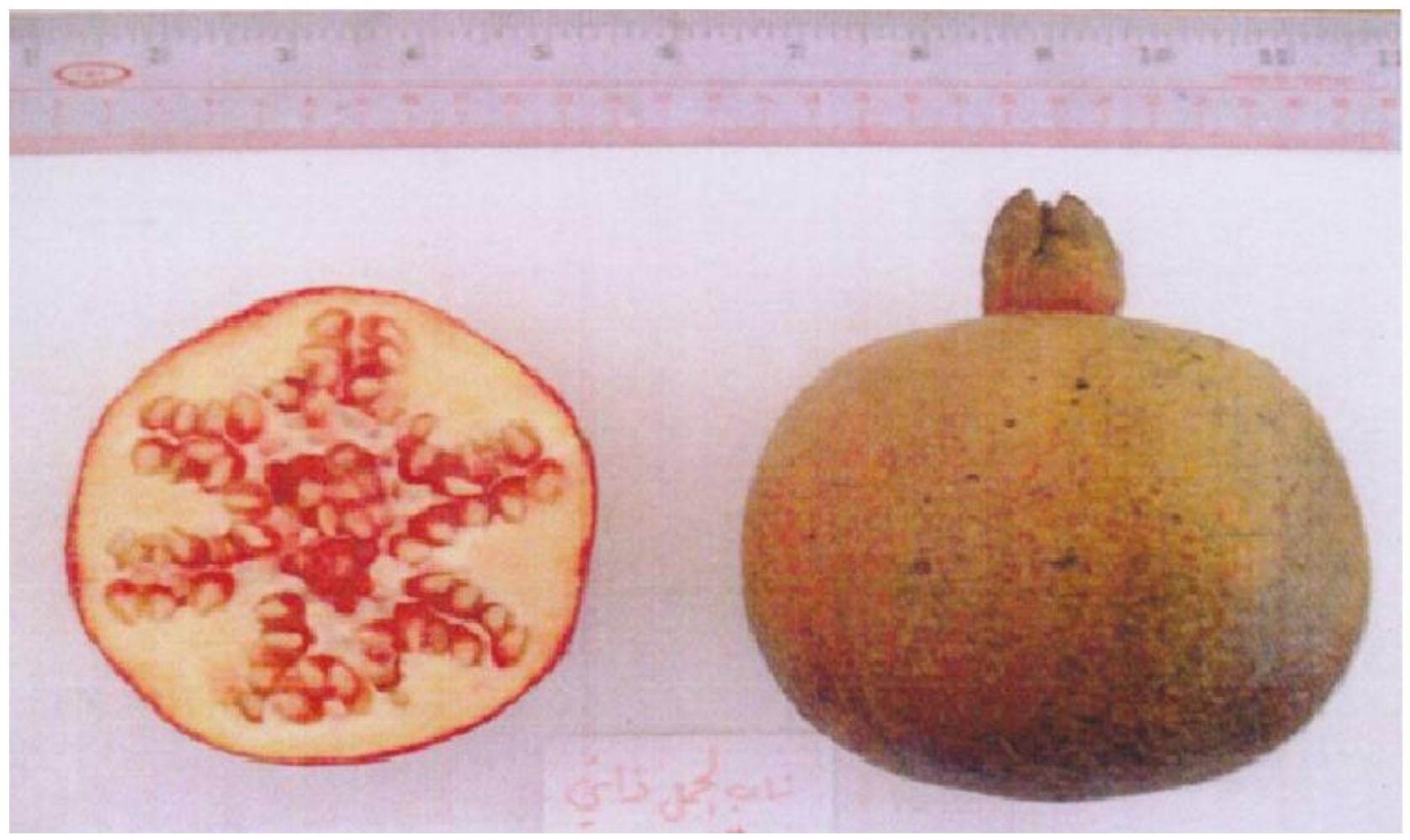

Fig. (1): pomegranate fruit of the resulting progenies under self of Nab-EI Gamal.

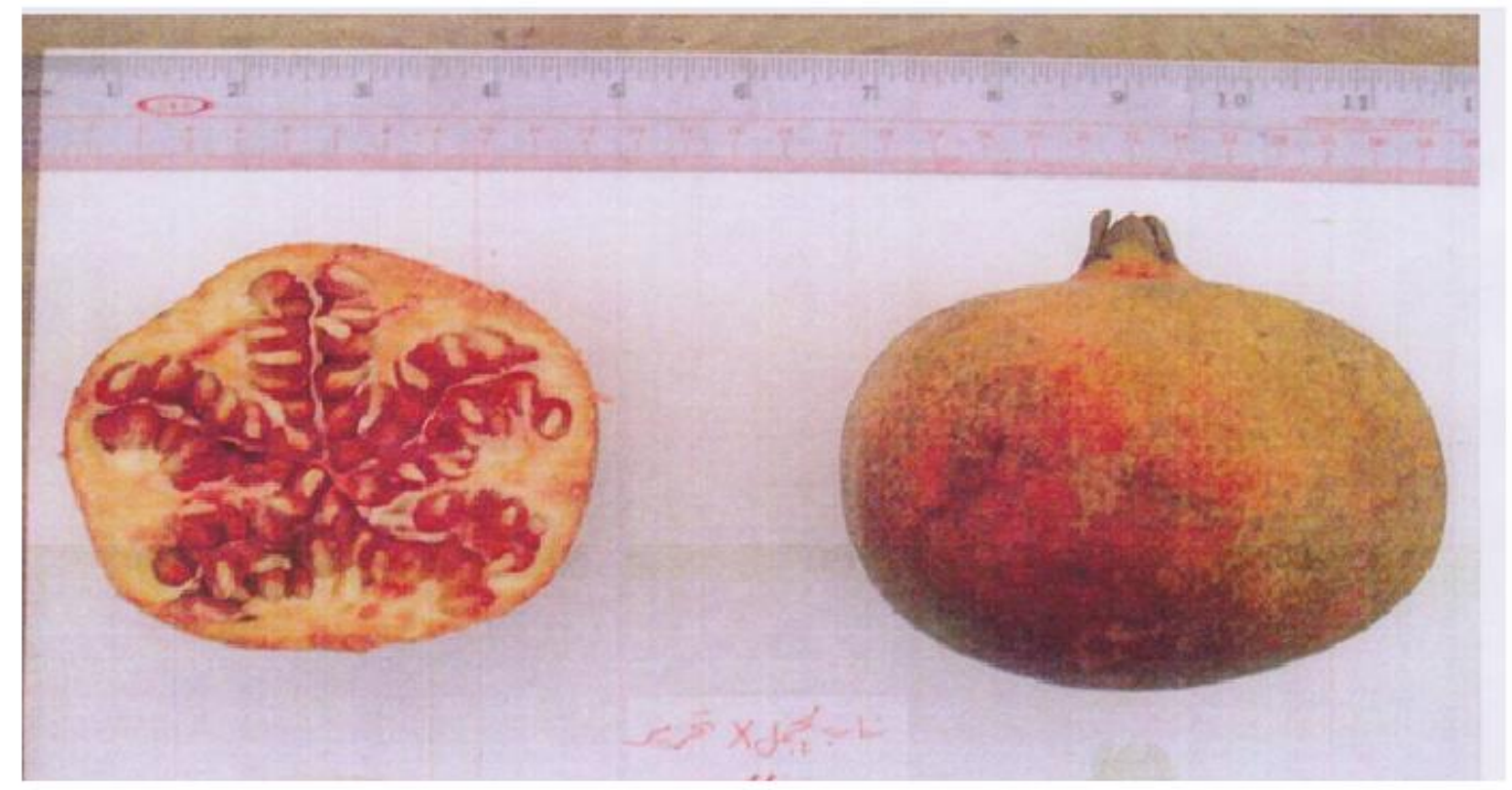

Fig. (2): pomegranate fruit of the resulting progenies under the hybrid between El-Tahrir X Nab-El Gamal cultivars. 


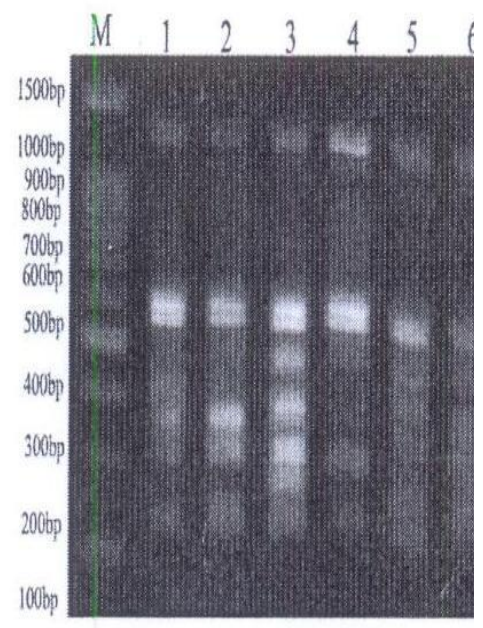

HB-12

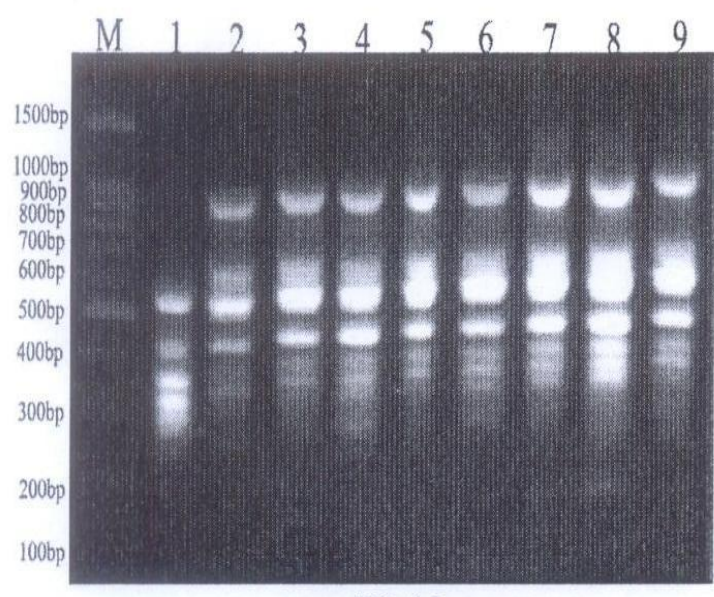

$\mathrm{HB}-15$

Fig. (3): DNA polymorphism of nine progenies of pomegranate amplified with ISSR primers. 1- Nab-El Gamal(O) (T1), 2- El-Tahrir(O) (T2), 3- Nab-El Gamal (S) (T3), 4- Nab-El Gamal (S) (T4), 5- El-Tahrir (S) (T5), 6- El-Tharir (S) (T6), 7- El-Tahrir x Nab-El Gamal (T7), 8- El-Tharir x Nab-El Gamal (T8) and El-Tahrir x Nab-El Gamal (T9).

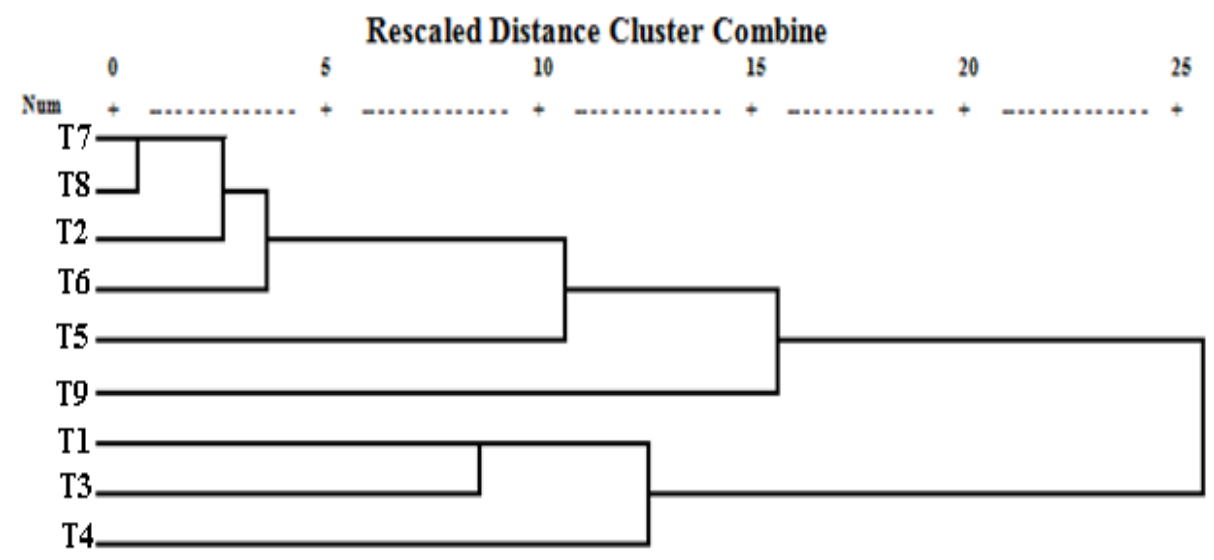

Fig.(4): Dendrogram of the nine progenies of pomegranate genotypes based on ISSR markers. 
Table (9): Similarity indices among progenies of Nab El-Gamal (N), and El-Tahrir (T) measured by Nei coefficient methods for ISSR data.

\begin{tabular}{|l|c|c|c|c|c|c|c|c|c|}
\hline & $\begin{array}{c}\text { N-open } \\
\text { T1 }\end{array}$ & $\begin{array}{c}\text { N-self } \\
\text { T3 }\end{array}$ & $\begin{array}{c}\text { N-self } \\
\text { T4 }\end{array}$ & $\begin{array}{c}\text { T-open } \\
\text { T2 }\end{array}$ & $\begin{array}{c}\text { T-self } \\
\text { T5 }\end{array}$ & $\begin{array}{c}\text { T-self } \\
\text { T6 }\end{array}$ & $\begin{array}{c}\text { Hybrid } \\
\text { T7 }\end{array}$ & $\begin{array}{c}\text { Hybrid } \\
\text { T8 }\end{array}$ & $\begin{array}{c}\text { Hybrid } \\
\text { T9 }\end{array}$ \\
\hline N-open(T1) & & & & & & & & & \\
\hline N-self(T3) & 0.81 & & & & & & & & \\
\hline N-self (T4) & 0.75 & 1.00 & & & & & & & \\
\hline T-open(T2) & 0.43 & 0.53 & 0.06 & & & & & & \\
\hline T-self (T5) & 0.18 & 0.26 & 0.40 & 0.55 & & & & & \\
\hline T-self(T6) & 0.29 & 0.05 & 0.33 & 0.74 & 0.92 & & & & \\
\hline Hybrid(T7) & 0.70 & 0.80 & 0.41 & 0.04 & 0.20 & 0.10 & & & \\
\hline Hybrid(T8) & $\mathbf{0 . 5 0}$ & $\mathbf{0 . 6 0}$ & $\mathbf{0 . 2 2}$ & $\mathbf{0 . 0 5}$ & $\mathbf{0 . 3 0}$ & $\mathbf{0 . 1 1}$ & $\mathbf{0 . 0 0}$ & & \\
\hline Hybrid(T9) & $\mathbf{0 . 6 9}$ & $\mathbf{0 . 2 1}$ & $\mathbf{0 . 6 0}$ & $\mathbf{0 . 4 1}$ & $\mathbf{0 . 1 6}$ & $\mathbf{0 . 2 7}$ & $\mathbf{0 . 3 5}$ & $\mathbf{0 . 0 6}$ & \\
\hline
\end{tabular}

pollinated genotypes of Nab-El Gamal (T3 and T4). The second sub-group contained hybrid T8, hybrid (T9) and the open pollinated genotype of Nab-El Gamal. Some investigations reported that the clustering of the cultivars is not related to the geographical distance (Jbir et al., 2006).

\subsubsection{Unique markers identified by ISSR markers}

Genotype specific ISSR unique markers could distinguish six out of the nine studied progenies (Table 10). Only, the hybrid progeny T9 (El-Tahrir X Nab-El Gamal) was characterized by both positive and negative unique markers, the five remaining progenies were identified by either positive or negative unique markers.

El-Tahrir self pollinated progenies (T5) was characterized by one unique positive marker by HB-08 primer at $935 \mathrm{bp}$. On the other hand, ElTahrir self pollinated progeny (T6) was identified by five positive unique markers with approximately molecular weight ranging from 115 to $840 \mathrm{bp}$ with for different primers (HB08,HB-11,HB-12 and HB-13). The two self pollinated progenies of Nab-El Gamal ( T3 and T4) were characterized by negative unique markers, the self pollinated progeny (T3) was identified by three markers, one of them by HB12 (400 bp), were remaining two markers were identified by HB-15 (115 and 230 bp). Whereas, the open pollinated progeny of Nab El-Gamal (T1) was characterized by two negative markers (630 bp and $880 \mathrm{bp}$ ) with primer HB-15.

Hybrid (T7) was identified by two unique

Table (10): Unique positive and negative markers as detected by ISSR markers.

\begin{tabular}{|c|c|c|c|c|c|c|c|}
\hline \multirow[b]{2}{*}{ Genotype } & \multicolumn{3}{|c|}{ Unique positive markers } & \multicolumn{3}{|c|}{ Unique negative markers } & \multirow[b]{2}{*}{ Grand Total } \\
\hline & $\begin{array}{c}\text { Size of } \\
\text { marker } \\
(\text { bp })\end{array}$ & Primer & $\begin{array}{l}\text { Total \# of } \\
\text { markers/ } \\
\text { genotype }\end{array}$ & $\begin{array}{c}\text { Size of } \\
\text { marker } \\
(\text { bp })\end{array}$ & primer & $\begin{array}{c}\text { Total \# of } \\
\text { marker/g } \\
\text { enotype }\end{array}$ & \\
\hline El-Tahrir Self (T5) & 935 & HB-08 & 1 & --- & --- & --- & 1 \\
\hline \multirow{4}{*}{ El-Tahrir Self (T6) } & 840-690 & HB-08 & \multirow{4}{*}{5} & \multirow{4}{*}{--- } & \multirow{4}{*}{--} & \multirow{4}{*}{--- } & \multirow{4}{*}{5} \\
\hline & 360 & HB-11 & & & & & \\
\hline & 115 & HB-12 & & & & & \\
\hline & 840 & HB-13 & & & & & \\
\hline \multirow{2}{*}{ Nab-El Gamal Self (T3) } & \multirow{2}{*}{---} & \multirow{2}{*}{---} & \multirow{2}{*}{--- } & 400 & HB-12 & \multirow{2}{*}{3} & \multirow{2}{*}{3} \\
\hline & & & & $230-115$ & HB-15 & & \\
\hline Nab El-Gamal Open (T1) & $--\cdot$ & --- & --- & $880-630$ & HB-15 & 2 & 2 \\
\hline \multirow{2}{*}{ Hybird (T7) } & 260 & HB-08 & \multirow{2}{*}{2} & \multirow{2}{*}{---} & \multirow{2}{*}{--- } & \multirow{2}{*}{--- } & \multirow{2}{*}{2} \\
\hline & 1260 & HB-12 & & & & & \\
\hline \multirow{2}{*}{ Hybird (T9) } & \multirow{2}{*}{610} & \multirow{2}{*}{ HB-08 } & \multirow{2}{*}{1} & 480 & HB-08 & \multirow{2}{*}{2} & \multirow{2}{*}{3} \\
\hline & & & & 710 & HB-11 & & \\
\hline 6 Genotypes & & & 9 & & & 7 & 16 \\
\hline
\end{tabular}


positive markers at $260 \mathrm{bp}$ and $1260 \mathrm{bp}$ with HB-08 and HB-12, respectively. The molecular data represented in this study are in harmony with those reported by Awamleh et al. (2009); Ebrahim et al. (2010) and Hasnaoui et al. (2010).

\section{Acknowledgement}

This research is dedicated to the soul of the late. Prof. Dr. Mostafa Atef El-Hamady, Professor of Pomology, Faculty of Agriculture, Kafre lsheikh University, and Supervisor of the Breeding Research Department, Horticultural Research Institute of A. R.C.

\section{REFERENCES}

Abou El-Khashab A. M., El-Iraqy M.A. and Essa K.B. (2005). Evaluation of some pomegranate (Punica granatum L.) cultivars under new reclaimed region. Egypt. J. Agric. Res., 2: (1) 59-70.

Aradhya M. (2006). Low genetic diversity and lack of genetic differentiation in Punica as evidenced by amplified fragment length polymorphysms, P. 64 In: ISHS, I ${ }^{s t}$ Int. Symp. Pomegranate and Minor Mediterranean Fruits, Abstracts contributed papers, 16-19 Oct., Adana. Turkey.

Awamleh H., Hassawi D., Migdad H. and Brake M. (2009). Molecular Characterization of pomegranate (Punica granatum L.) landrace grown in Jorden using amplified fragment length polymorphism markers. Biotech. 8: 316-322.

Bist H.S., Srivastava R. and Sharma G. (1994). Variation in some promising selections of wild pomegranate (Punica grnatum L.). Hort. J., 7: 67-70.

De Candolle A., (1967). In: Orgin of Cultivated Plants, pp: 237-240. Hafner Publication, Co. New York and London.

Ebrahimi S., Sayed T. and Sharifinab B. (2010). Microsatellite isolation and Characterization in pomegranate (Punica granatum L.) Iran J. Biotech., 8: 156-163.

El-Kasses S.E., El-Sesesee A.M., El-Salhy A. M. and Abdella A. A. (1998): Bearing habits in some pomegranate cultivars. Assiut J. Agric. Sci. 29 (3):147-162.

Feng Yuzheng, Chen Dejun, Song MeiTing, Zhao YanLi, L. Zhanhong and $\mathrm{Li}$ Zongquan (1998): Assessment and utilization of pomegranate cultivars resources. Henan province J. Fruit. Sci. 15
(4): $370-373$.

Gomez K.A. and Gomez A.A. (1984). Statistical Procedures for Agricultural Research $2^{\text {nd }}$ Ed. John Wiley, New York, USA.

Hasnaoui N., Mars M., Chibani J. and Trifi M. (2010). Molecular polymorphism in Tunisian pomegranate (Punica granatum L.) as revealed by DNA fingerprints. Diversity 2: 107-114.

Jalikop S.H. and Kumar P.S. (1998). Use of soft, semisoft and hard seeded types of pomegranate (Punica granatum L.) for improvement of fruit attributes. Indian $\mathrm{J}$. Agric. Sci., 68: 87-91.

Jbir R., Hasnaoui N., Trifi M., Marrakchi M. and Mars M. (2006). Molecular polymorphism in Tunisian pomegranate (Punica granatum L.) cultivars as related by AFL PP. 71 In: ISHS $1^{\text {st }}$.IntSymp. Pomegranate and Minor Mediterranean Fruits Abstracts contributed papers, 16-19 Oct. Adana. Turkey.

Josan J.S., Jawanda J.S. and Uppal D.K. (1979). Studies on the floral biology of pomegranate. II: Anthesis, dehiscence, pollen studies and receptivity of stigma. Punjab Hort. J., 19: 66-70.

Khalil A., SaadAlla M., El-Said M., El-Deen Ekram S. and El-Kateeb A. (1985). Selection in the seedling progeny of pomegranate. Ann. Agric. Sci. Fac. Agric. Ain Shams Univ. Egypt, 30 (2): 15131522.

Khodade M.S., Wavhal K.N. and Kale P.N. (1990). Physio-chemical changes during growth and development of pomegranate fruit. Indian J. Hort., 47: 21-27.

Levin G. M. (1990). Problems of methodological breeding in pomegranate. SubtropicheskieKul'tury, 6: 70-73 (In Russian, English abstract).

Mars M. and Marrakchi M. (1999). Diversity of Pomegranate (Punica granatum L.) germplasm in Tunisia. Genet. Resour. Crop Evol. 46:461-476.

Mir M.M., Jhon A.Q., Khan F.U. and Nelofar (2007a). Studies on physical and chemical characteristic of pomegranate cultivars in Kashmir valley. J. Hort. Sci., 2: 139-142.

Mir M. M., Sofi A. A., Singh D.B. and Khan F.U. (2007b). Evaluation of pomegranate cultivars under temperate conditions of Kashmir Valley. Indian J. Hort., 64: 150154.

Nalawadi U. G., Farooqui A. A., Dasappa M. A. 
Narayana Reddy, Gubbaiah, Sulikeri G.S. and Nalini A.S. (1973): Studies on the floral biology of pomegranate (Punica granatum L.). Mysore J. Agric. Sci., 7:213-225.

Nath N. and Randhawa G.S., (1959a). Studies on floral biology of pomegranate II: Anthesis, dehiscence, pollen studies and receptivity of stigma. Indian J. Hort., 16: 121-135.

Nath N. and Randhawa G.S., (1959b). Studies on floral biology of pomegranate III: Pollination, fruitset and seed formation. Indian J. Hort., 16:136-140.

Nei M. and Li W. (1979). Mathematical model for studying genetic variation in terms of restriction endonucleases. Proc Nat .Acad. Sci .U S A. 76 (10): 5269-5273.

Pasad R. N. and Banker G. J. (1999). Evaluation of pomegranate for processing. Sci. Hort. 6: 5-7.

Porebski S., Bailey L.G. and Baum B. R. (1997). Modification of a CTAB DNA extraction protocol for plants containing high polysaccharide and polyphenol components. Plant Mol. Bio. Rep.,15:815.

Shulman Y., Fainberstein L. and Lavee S. (1984). Pomegranate fruit development and maturation. J. Hort. Sci., 59:265-274.

Singh J. (1977). Studies on floral biology of pomegranate (Punica granatum L.) M. SC. (Ag) Thesis, Punjab Agriculture University, Ludhiana. India.

Singh R. P., Kar P.L. and Dhuria H.S. (1978). Studies on the behaviour of flowering and sex expression in some pomegranate cultivars. Plant Sci., 10: 29-31.

Simith P. M. (1976). Minor Crops. In: Simmonds, N.W. (ed), Evaluation of crop plants, PP:312-313. Longman. London.

Sukran D., Gunes T. and Sivaci R. (1998). Spectra photometricn determination of chlorophyll. A, B and total carotenoid contents of some algae species using different solvents. Tr. J. Bot., 22: 13-17.

Varasteh F., Argani K., Zamani Z. and Mohseni A. (2009). Evaluation of the most important characteristics of some commercial pomegranate (Punica granatum L.) cultivars grown in Iran. Acta Hort., 818: 1030-1038.

Vechetel B.W. and Ruppel H.G. (1992). Lipid bodies in Eremosphaera viridis De Bary (Chiorophyceae). Plant and Cell Physiol. 31: 41-48.

Yilmaz M., Aka-Kacer Y., Yalcin-Mendi Y. and Ozguven A.I. (2006). Molecular characterization of some pomegranate (Punica granatum L.) genotypes by RAPD markers. PP.72 In:ISHS. $1^{\text {st }}$ Int. Symp. Pomegranate and Minor Mediterranean Fruits, Abstracts contributed papers, 16-19 Oct., Adana. Turkey.

Zamani Z., Sarkhosh A., Fatahi R. and Ebadi A. (2007). Genetic relationships among pomegranate genotypes studied by fruit characteristics and RAPD markers. J. Hort. Sci. Biot., 82: 11-18.

Zukovskiy P. M. (1950). Punica. Cultivated Plants and Their Wild Relatives. PP. 6061 In: State Publ. House Soviet Scie., Moscow.

\footnotetext{
الانتخاب والتقييم للاختلافات الور اثية في الرمان 
محصول (22 كيلوجر ام/ شجرة). و الثجرة الأولي و الثانية من نفس الهجين أعـطو ا أحسن نسبة من المــو اد الصلبة الكلية

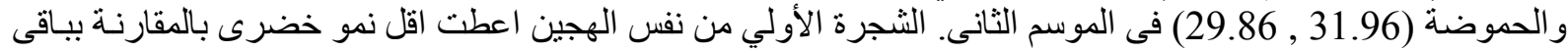

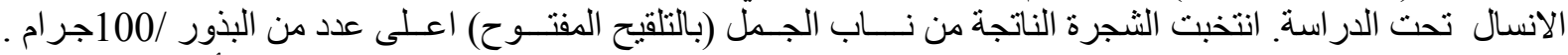

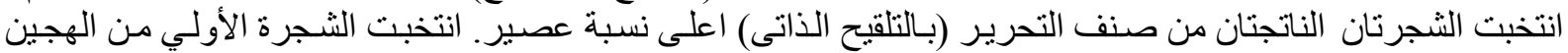

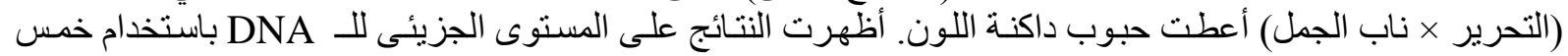

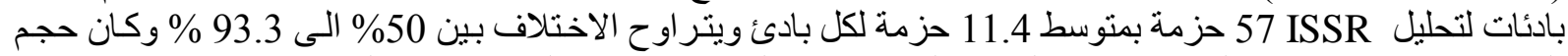

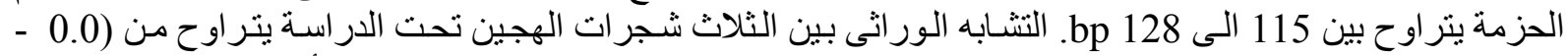

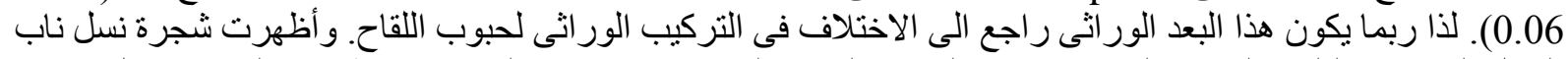

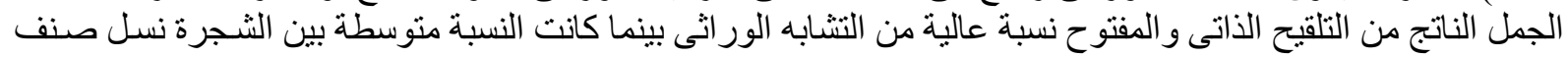

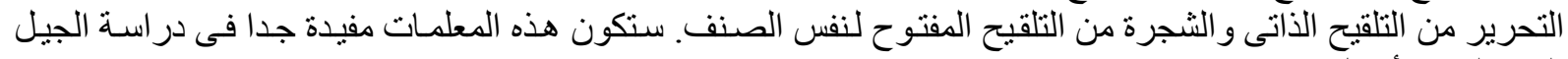

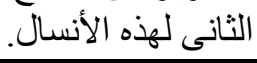
المجلة العلمية لكلية الزراعة - جامعة القاهرة ـ المجلا (65) العدد الثالث (يوليو 2014) 303-317. 